DOI:10.17951/bc.2021.6.27-48

\begin{tabular}{lcr}
\hline & ANNALES \\
& UNIVERSITATIS MARIAE CURIE-SKŁODOWSKA & \\
LUBLIN - POLONIA & \\
VOL.VI & SECTIO M & 2021 \\
\hline
\end{tabular}

Katarzyna Marzęda-Mtynarska

Maria Curie-Skłodowska University in Lublin, Poland

katarzyna.marzeda@poczta.umcs.lublin.pl

ORCID ID: https://orcid.org/0000-0002-4608-7290

\title{
Europeanization of Polish Historical Policy - From Ignorance To Understanding?
}

\section{Introduction}

On August 30th, 2021, Russian Foreign Minister - Sergei Lavrov said to WW2 veterans, that to attack Stalin is an attack on Russian past, design to undermine the results of WW2. He also said that rewriting history is an attempt to weaken Russian Federation politically ${ }^{1}$. Such a statement, made by the foreign minister of Russia two days before the $82^{\text {nd }}$ anniversary of the outbreak of WW2 has a strong political overtones, which demonstrate that history and its interpretation is still a battlefield, where it is not the historical truth that matters, but the strength of the narrative to promote one's own vision of history. For Poland, which was deprived of the possibility to tell its own story and to participate in the international historical discourse due to 45 years of communist regime, historical policy has become particularly important, especially in countering harmful stereotypes and distorted imagery.

1 Website TVN24, https://tvn24.pl/swiat/siergiej-lawrow-ataki-na-stalina-to-ataki-narosyjska-przeszlosc-5335925, „Sergiej Ławrow staje w obronie Stalina i mówi o atakach na rosyjską przeszłość", access 30 VIII 2021. 
The process of Europeanization of Polish foreign policy, which can be understood as a concept explaining the foreign policy interactions between the European Union and member states with a special emphasis on issues relating to influencing the EU's external relations ${ }^{2}$, has become a particularly important mechanism for strengthening the audibility of the Polish historical narrative. Through EU membership, Poland has gained a new channel of communication and promotion of its own historical narrative after 1989, and an important ally in European institutions in the fight against disinformation and rewriting of history, especially that related to WW2.

The paper aims to analyse the process of Europeanization of Polish historical policy on WW2 in two dimensions: first, the internal, i.e. to answer the question to what extent Poland's membership in the EU has influenced the internal discourse around historical policy?, and second, the external, i.e. to what extent Poland has influenced historical awareness of the member states and the position of European institutions regarding historical issues related to WW2?

For the purpose of the analysis, the model of Europeanization of foreign policy ${ }^{3}$ will be used. This is based on two mechanisms: downloading - understood as a transfer of EU preferences to the state level, and uploading - transferring of national preferences to the EU level ${ }^{4}$. It should be noted however, that the use of such methodology required adopting a narrow approach to the historical policy, by limiting it solely to the external dimension. Taking this perspective does not, however, mean, separation of historical policy from national historical discourse or narrative. On the contrary. Although most authors agree that there are two dimensions to historical policy: internal and external ${ }^{5}$, both are shaped by a historical narrative constructed at the national level, which can be

2 J. Kamińska, Europeizacja polskiej polityki zagranicznej, htps://www.ce.uw.edu.pl/pliki/ pw/3-2008_Kaminska.pdf, access 30 VIII 2021.

3 J. Kamińska, Europeizacja polskiej polityki zagranicznej...

4 C. Major, Europeanization of Foreign and Security Policy - Undermining or rescuing the nation state?, „Politics”, 2005, vol. 25(3), p. 175-190; R. Wong, The Europeanization of Foreign Policy [in:] International Relations and the European Union, ed. by C. Hill, M. Smith, Oxford University Press, Oxford 2011, p. 149-170.

5 Polityka historyczna - za i przeciw, Dyskusja z udziałem P. Dukielskiego, M. Cichockiego, M. Kuli, A. Wernera, K. Mazura, „Mówią Wieki”, 2006, no 8, p. 10; A. Wolff-Powęska, Polskie spory o historię i pamięć. Polityka historyczna, „Przegląd Zachodni”, 2007, no 1, p. 3-44; K. Kącka, Polityka historyczna: kreatorzy, narzędzia, mechanizmy działania - przykład Polski [in:] Narracje pamięci. Między polityka a historia, ed. K. Kącka, J. Piechowiak-Lamparska, A. Ratke -Majewska, Wydawnictwo Naukowe UMK, Toruń 2015, p. 59-82; E. Ponczek, Polityka historyczna w Polsce - od ogladu retrospektywnego do refleksji o następstwach przyszłościowych [in:] Narracje pamięci. Między polityka a historia, ed. K. Kącka, J. Piechowiak-Lamparska, A. RatkeMajewska, Wydawnictwo Naukowe UMK, Toruń 2015, p. 29.58. 
used to achieve internal political goals - e.g. winning elections, or external strengthening/improving state image or building understanding for decisions taken. It also means that historical policy and historical narration should be treated as separate but related phenomena.

The time frame of analysis is determined by Poland's membership in the EU - from 2004 to current times, however, in part two, the analysis also refers to the period prior to 2004. Due to the fact that in 1989, when it regained its sovereignty, Poland was confronted with a number of already existing historical narratives related to World War 2, the analysis will focus on the process of construction of Polish historical discourse on WW2 in the condition of EU membership, and how it has affected Polish historical policy.

The paper consists of four parts. The first briefly explains the model of Europeanization of foreign policy as an analytical tool and its adaptation to the analysis of state's historical policy. The second, presents the Polish historical narrative of the WW2 constructed after 1989 and its key elements. The third (downloading) explores the WW2 historical narrative existed at European level, identifies its fits and misfits, and how they have affected Polish historical policy. The fourth (uploading) analyzes how Poland used EU membership to promote its own historical narrative to shape historical awareness at the European level. The analysis is based on primary and secondary sources, mainly Polish, including official websites of Polish and European institutions, experts opinions, interviews and comments.

\section{The Europeanization of Foreign Policy model and its utility in the context of state's historical policy analysis}

While many definitions of the Europeanization process exist in subject literature $^{6}$, in the broadest sense, it can be understood as the influence of the EU on policies at national level 7 . When limited to the foreign policy, it is interpreted as a 'two way' process: top-down (downloading) - the influence of the EU on a foreign policies of its member states, by transfer of 'European preferences', and bottom-up (uploading) - the influence of the member states on EU foreign policy, by transfer of national preferences. Although many researchers have pointed out that EU influence (thus, the Europeanization process) on national foreign

${ }^{6}$ M. Cowles, J. Caporaso, T. Risse, Europeanization and domestic change. Transforming Europe, Cornell University Press, New York 2001; The politics of Europeanization, eds. C. Radelli, K. Featherstone, Oxford University Press, Oxford 2003; J. Olsen, Many faces of Europeanization, „Journal of Common Market Studies” 2002, vol. 40, no 5, p. 921-952.

7 J. Kamińska, Europeizacja polskiej polityki zagranicznej... 
policies is weak, due to the lack of formal conditions that the candidate country must meet in foreign policy in order to become a member ${ }^{8}$, the manifestations of the Europeanization of foreign policy can be easy observed. For example, in the form of the EU member states vote in the UN General Assembly, in line with the position of the EU institutions.

For the purpose of the following analysis, the model of Europeanization of foreign policy will be understood as: first, a change in the formulation of this policy, second, a change in national preferences, third, a change in the behavior of ruling elites, and fourth, a change in the framework of institutional cooperation'. While 'change' is a key category for this model, it is conceptualized as a result of adaptative pressure during the integration process that is determined by two factors - the fits and misfits of national preferences to European ones ${ }^{10}$ - the scale of which allows observation of the Europeanization process.

The usefulness of the Europeanization model is also due to the criteria of evaluation of the scale of 'downloading' and 'uploading'. In the downloading context - the following determinants were identified: 1 / socialization of elites; 2 / institutional/administrative changes; 3 / legal changes and 4/ changes in public opinion $^{11}$. In the case of uploading: $1 /$ development of new institutional cooperation frameworks/ using and building international coalitions; 2/ influence and deciding about the European agenda; 3/ setting by example and 4/ export of ideas to the European level ${ }^{12}$.

Although, the presented model was developed to analyze the Europeanization of foreign policy of the EU member states, it requires adaptation when applied to historical policy, even if we recognize this as a part of foreign policy. The problem is not only the subjectivity of national memory, but, above all, the different historical sensitivity of individual countries, motivated by their political interests or political interest of ruling party. The existence of a given historical narrative is not always the result of popular awareness, but rather of political

8 C. Radelli, The Europeanization of public policy [in:] The politics of the Europeanization, eds. C. Radelli, K. Featherstone, Oxford University Press, Oxford 2003, p. 27-56; H. Grabbe, How does the Europeanization affect the CEE governance? Conditionality, diffusion and diversity, „Journal of European Public Policy”, 2001, vol. 8, issue 6, p. 1013-1031.

9 J. Kamińska, Europeizacja polskiej polityki zagranicznej...

10 T. Börzel, T. Risse, Conceptualizing the Domestic Impact of Europe [in:] The politics of Europeanization, eds. R. Featherstone, C. Radelli, Oxford University Press, Oxford 2003, p. 57-82.

11 M. E. Smith, Conforming to Europe: the domestic impact of the EU policy cooperation, „Journal of the European Public Policy” 2000, vol. 7, issue 4, p. 617.

12 A. Miskimmon, W.E. Paterson, Foreign and Security Policy: On the Cusp Between Transformation and Accommodation [in:] Germany, Europe and Politics of Constraint, eds. K. Dyson, K.H. Goetz, Oxford University Press, Oxford 2004, p. 325-346. 
calculation, which makes it difficult to subject it to the objective criteria of evaluation. Therefore, the model was slightly modified for the purpose of this study. The following 'methodology' based on the Europeanization of foreign policy was developed. It distinguishes successive actions (steps), which are to serve the implementation of the defined research objective:

I. Identification of Polish historical narrative related to WW2, with its key elements after 1989.

II. Identification of historical narrative related to WW2 at the European level.

III. Comparison of Polish and European narratives related to WW2 by identification fits and misfits.

IV. Evaluation how the identified misfits have influenced Polish historical policy in following dimensions:

a. internal historical debate / public opinion changes;

b. content of historical policy / official historical policy changes;

c. institutional / administrative changes;

d. regulations changes.

V. Evaluation how Poland through its image and public diplomacy has affected the European historical narrative by exploring:

a. support to its historical initiatives (anniversaries, commemorations);

b. influence on the official agenda of the EU institutions related to WW2 (position documents, statements, debates);

c. changes in the European historical discourse (media);

d. changes in public opinion related to WW2.

Poland's historical narrative related to WW2 after 1989 and its key elements

'History influences politics, politics influences history'13. This simple, yet true observation is particularly relevant in the case of Poland. Since independence in 1918, the memory of past calamities has determined political choices of Poland, especially in the sphere of foreign and security policy. Accordingly, history was used in the interwar period to build patriotic attitudes and support to the newly independent country - but first of all, to learn from the past how to avoid the mistakes that resulted in the partitioning of Poland for more than one hundred years. It was also that period when negative experiences of relations with neighboring countries gave Poland's historical policy a geopolitical dimension, positioning it "between the historical policies of its great neighbors"14.

\footnotetext{
${ }^{13}$ A. Wolff-Powęska, Polskie spory o historię i pamięć..., p. 13.

${ }^{14}$ Ibidem, p. 34.
} 
The experiences of WW2 only strengthened this tendency. As a result of the war's traumatic events, symbols, myths and syndromes were formed that still affect ${ }^{15}$, and fuel internal historical discourse, and resonate through the historical narratives of Germany and Russian Federation, which are interpreted (rightly or not) as a rewriting of history.

The political instrumentalization of history was particularly present during communist times. The dominant historical narrative at that time was dialectical, strongly ideologized and reductionist. Historical discourse in communist Poland was based on Marxism, which emphasized the class basis of all conflicts. For that reason, the internationalist approach to historiography was introduced, in which the existence of nation states was seen as an obstacle to the establishment of world communism. The selectivity and subordination to ideological purposes resulted in a narrative detached from historical facts. Only those that fit the official party line, like that about the Polish and Soviet proletariat's brave victory over fascism, as a result of which the historic Polish lands under German domination finally returned to the Polish motherland, were emphasized. Any manifestations of a different interpretation, incompatible with the guidelines of the party ideologists and historians were suppressed ${ }^{16}$.

Democratic Poland's regaining of sovereignty has opened up the discussion about its past, and especially about the WW2 era. The so-called "white spots" - events omitted in the official version of WW2 history during communist times, were in the center of historical discourse of the first years of democratic transition. This was dominated by the Katyn massacre, the force deportation of Polish citizens by Soviets, the Ribbentrop-Molotov Pact, and the war effort of Poles who fought on the frontlines of World War 2 alongside the Western Allies, and whose contribution was almost unknown to general public. The memory of the horrific crimes committed against Polish citizens by Nazi-Germany during occupation was supplemented by the memory of Soviet crimes against Poles, symbolized by Katyn and deportations.

While in the period just after regaining sovereignty the focus was mainly on 'white spots' in Polish history, after obtaining EU membership, the attention of the creators of Poland's historical narration has been focused mainly on the reconstruction of facts, effects and causes, giving meaning to history and

15 A. Włodkowska-Bagan, Kultura strategiczna Polski [in:] Polityka zagraniczna Polski $w$ zmieniającym się ładzie międzynarodowym, ed. R. Zięba, T. Pawłuszko, Wydawnictwo Uniwersytetu Jana Kochanowskiego w Kielcach, Kielce 2016, p. 58.

${ }_{16}$ J.Z. Sawicki, Pamięć i polityka historyczna na przykładzie walski z legenda powstania warszawskiego [in:] Narracje pamięci. Między polityka a historia, ed. K. Kącka, J. PiechowiakLamparska, A. Ratke-Majewska, Wydawnictwo Naukowe UMK, Toruń 2015, p. 133-146. 
the way history was communicated ${ }^{17}$. That approach found special expression in the operations of a new institution: the Institute of National Remembrance established in 1999, which aims to "research and popularize the modern history of Poland", and to "investigate crimes against Polish nation from 8 November 1917 to 31 July $1990 " 18$.

The establishment of the Institute has contributed to the consolidation of a patriotic - 'conservative'19 historical narrative about World War 2, based on a positive image of the history of the nation and the state, to appreciate the heroism of national heroes and to show the sense of martyrdom, often accompanied by ignoring events with a high degree of complexity and ambiguous interpretations, or which directly depict the nation or part of it in a bad light ${ }^{20}$. In an attempt to reconstruct the content of the Polish patriotic narrative about World War 2, it can be reduced to a few key elements:

- it was Poland that become the first victim of Nazi-German aggression,

- Poland was the first country that put up strong armed resistance to Hitler and fought on all fronts of World War 2,

- Poland suffered huge material and population losses during World War 2, losing nearly $20 \%$ of its citizens;

- Polish citizens were victims of two totalitarian regimes: Nazi and Communist.

- Poles are always presented as a heroes or victims, not as a perpetrators.

The victim syndrome is especially interpreted, on the one hand, as a consequence of the criminal actions of both occupants, on the other, as a consequence of "negative experiences of the appeasement policy, abandonment by the allies in September 1939 and the Yalta betrayal" ${ }^{21}$, and is deeply rooted in the Polish narrative about WW2.

It should be, however, emphasized that, the patriotic historical narrative about WW2 was not accepted without reservation. On the contrary - it has become the subject of heated debates, especially when it was included into the historical policy of the national-conservative ruling coalition, which took power in Poland in 2005, and a new conservative President, elected the same year. It is argued that while the historical policy between 1989 and 2005, was

\footnotetext{
17 A. Wolff-Powęska, Polskie spory o historię i pamięć..., p. 15.

${ }_{18}$ Institute of National Remembrance, https://ipn.gov.pl/en/about-the-institute, About the Institute, access 3 IX 2021.

19 A. Dudek, Historia i polityka w Polsce po 1989 roku [in:] Historycy i politycy: polityka pamięci w III RP, ed. P. Skibiński, T. Wiścicki, M. Wysocki, Wydawnictwo DiG oraz Muzeum Historii Polski, Warszawa 2011, p. 38.

${ }^{20}$ Ibidem, p. 39-40.

${ }^{21}$ A. Włodkowska-Bagan, Kultura strategiczna Polski..., p. 63.
} 
a part of everyday political work, without unnecessary declarations and verbal signs $^{22}$, since 2005 it has been transformed into one of the specific policies of the government, aimed at shaping the scope and character of collective historical memory, by imposing a single, common vision of the past ${ }^{23}$.

European narrative about WW2 and its influence on Poland's historical policy - The Downloading

The process of shaping the European narrative about WW2 can be described as a search for the 'common denominator' of individual national narratives. Although in literature, there can be found similar opinions about its content, there are, however, different perspectives on the sources of the processes that led to its creation. In the article "Swedish narrative of the Second World War: A European Narrative", J. Östling writes about the European 'universalistic' narrative, based on grievous, traumatic experiences - with the extermination of Europe's Jews in its center ${ }^{24}$. In his opinion, this new narrative was an effect of patriotic narratives contestations, which took place in Western Europe in 1980s and 1990s. Breaking the taboos existing in the national historical discourses, especially those concerning collaboration with Germans during WW2, has opened up again the discussion about political and moral dimensions of the past. As a result, the Jewish victims and their individual suffering were placed in the center of the discourse, what was accompanied by "the emergence of an official culture of grief and commemoration (...). States, organisations and individuals took the blame on themselves for crimes committed during the war"25.

The other interpretation traces the origins of the European WW2 narrative to the process of European integration. According to this view, European integration was design to avoid a repeat of WW2 in a future, and the process of building of a common Europe has brought to an end a period of mourning, revictimization and settlements. The result of this process was twofold - "relative relegation to the background of the suffering of other nations at the hands of Nazi Germany and the crimes of communism" and "the history of the Holo-

\footnotetext{
${ }^{22}$ A. Wolff-Powęska, Polskie spory o historię i pamięć..., p. 23.

${ }^{23}$ E. Smolar, Wtadza i geografia pamięci [in:] Pamięć jako przedmiot władzy, ed. P. Kosiewski, Fundacja im S. Batorego, Warszawa 2008, p. 56.

${ }^{24}$ J. Östling, Swedish Narratives of the Second World War: A European Perspective, "Contemporary European History", 2008, vol. 17, issue 2, p. 201.

${ }^{25}$ Ibidem, p. 202.
} 
caust, persecution and suffering took the place of the history of heroic deeds, struggle and resistance"26.

According to yet another interpretation, the historical paradigm (narrative) has changed after the mass protests in Europe in 1968. As a result, the heroic (patriotic) history was replaced by the two claims: first - that the subjects of war were not specific nations, but ideologies. And second, that common memory should focus on the civilian victims ${ }^{27}$. This has affected the European narrative about WW2 in two ways: by replacing of the guilt of Germans with the guilt of the Nazis (a term which dominates political and media space since then); and, by putting Holocaust victims in the center of historical discourse.

On comparing Polish and European historical narratives about WW2, we can observe significant differences in attitudes toward the war and the way it is remembered. While in Western Europe, the chapter of World War 2 has been finally closed, and the narrative developed at the European level does not rise major controversies. In Poland, however, the memory of WW2 is still alive and the narrative presented at the EU level has become the subject of fierce debates.

The opening up of Poland in 1989 led to confrontation with the European historical narrative of World War 2. It was a shocking experience for the Polish public opinion, especially in the placing of the Holocaust victims at the center of the narrative with the accompanying accusations of Poles for complicity in this crime. It was perceived (and still is) as putting Poles on an equal footing with the Nazi-German perpetrators and also as implying that Poland collaborated with the Nazi-German occupier, similar to action of many other European countries that had participated in the extermination of Jews in an institutionalized manner. For Poles who had experienced the brutality and extermination policy of the occupant to an extent unknown to many Western countries, such tailored narrative was, to say the least, controversial.

Not surprisingly then, for Poland, which in fact faced the legacy of the Holocaust only after regaining sovereignty in 1989 (during communism it was not a central point in the historical narrative), that vision of WW2 history was difficult to accept. The reasons for this reluctance were accurately pointed out by E. Smolar, indicating that, first, it is due to the communist silence about the Holocaust in Poland. Second - because apart from millions of Jewish victims, there were millions of Polish victims, which, combined with the first factor, did

\footnotetext{
${ }^{26}$ E. Smolar, Wtadza i geografia pamięci..., p. 69.

27 Website Teologia Polityczna, https://teologiapolityczna.pl/ii-wojna-swiatowa-i-wspolczesne-narracje-historyczne-rozmowa-z-piotrem-semka, II wojna światowa i wspótczesne narracje historyczne. Rozmowa $z$ Piotrem Semka, access 30 VIII 2021.
} 
not make it easy to understand the specificity of the Jewish martyrdom. Third, because apart from the victims of Nazism, there were also many victims of communism. Fourth, because in the memory of Poles, Jews - the victims, were simultaneously perceived as co-perpetrators of the Soviet crimes ${ }^{28}$.

The perception of Holocaust and the accusations of Poles of complicity in the extermination of Jews during the WW2 represent the biggest misfit between Polish and European narrative about WW2. Reactions to it, however, have not only affected the internal historical discourse in Poland, but also have strongly contributed to the polarization of both - public opinion and political scene. This polarization was particularly reflected in the historical policy, formulated and implemented by the political parties that ruled Poland after 1989, which took shape of two distinct models: liberal - characteristic to liberal and left-wing parties, and conservative (patriotic) - represented by national-conservative parties $^{29}$. The major difference between them (in the analyzed context) focuses on the way they respond to the European narrative. While the liberal model has fully internalized the European narrative of World War 2, the conservative has contested it.

The liberal model of historical policy was based on official neutrality of the state in the sphere of shaping the historical consciousness of Poles. This was based on the assumption that "Any attempt by the state to promote any historical values constitutes an 'official' adjudication of what is true" ${ }^{30}$. It did not, however, mean a resignation of state from influencing the historical awareness. On a contrary, there was a particular role to play for politicians and media. That is why the proponents of the liberal model of historical policy have accepted the European narrative about WW2 without major reservations. This fit between European and Polish narrative was particularly reflected in the policy of expiation, which characterized Polish historical policy between 1989 and 2005.

A specific manifestation of this policy was the response of the Polish authorities to the publication of the book "Neighbours" 31 , in which the participation of Poles in the murder of Jews in Jedwabne during World War 2 was described. In reaction to this accusation, Polish President - Aleksander Kwaśniewski apologized on behalf of Poles to the Jews for this horrific act, during official celebration of the 60th anniversary of this events in 2001. The so-called "Jedwabne case" was followed by the postulate of building a new historical identity of Poles by

\footnotetext{
${ }^{28}$ E. Smolar, Wtadza i geografia pamięci..., p. 70.

29 A. Dudek, Historia i polityka w Polsce po 1989 roku....

${ }^{30}$ Ibidem, p. 36.

31 J.T. Gross, Sasiedzi. Historia zagtady żydowskiego miasteczka, Wydawnictwo Pogranicze,
} Sejny 2000. 
the supporters of the liberal model. Its key element was rejection of a heroic and martyrological vision of Polish history that "obscures the unpleasant facts of the past for Poles, perpetuates antagonisms towards neighbours and makes it difficult to abandon the role of victim and to play an active and constructive role in the process of building a European identity" ${ }^{32}$.

Another example of realization of liberal historical policy in practice (and fit between European and Polish historical narratives), was a WW2 Museum opened in Gdansk in 2017, in which the universalistic narrative about the war dominates. The experiences of Poland and Poles were presented there against the background of the history of the whole of Europe and the world. The perspective also included the events that led to the war. The glory and heroism of the Polish soldiers gave way to a narrative of the suffering of the civilian population.

The conservative (patriotic) model of historical policy is based on completely different assumptions. Contrary to the liberal, in the conservative model, the state plays a critical role in shaping the historical awareness and patriotic attitudes of its citizens. Historical policy is perceived as a tool for strengthening the national community, as an effective means of mobilizing supporters and as an important element of foreign policy ${ }^{33}$. The conservative model found its expression in the historical policy of the Law and Justice party, which ruled Poland from 2005 to 2007 and won elections in 2015 and 2019. As a ruling party, Law and Justice has firmly rejected the liberal approach to reconciliation through apologizing and forgetting. Moreover, its historical policy has firmly rejected the EU"s universalist narrative of World War 2. As Jarosław Kaczyński - Law and Justice leader stated: "We are in danger of a situation in which in a few decades, or maybe even less, the Second World War will be two great crimes: The Holocaust, in which Poles allegedly took part, or the displacement of Germans, the work of Poles" ${ }^{34}$. That is why the Law and Justice put the historical awareness at the heart of its political program. Their ambition was to shape patriotic attitudes inside the country and counteract harmful stereotypes and opinions outside. "In times of growing historical ignorance in the world, it is a defence against pressure and distortion of history by other states" ${ }^{\prime 5}$. Moreover, for conservatives, historical policy was "a tool for strengthening the national community, accepting certain

${ }^{32}$ J.A. Majcherek, W poszukiwaniu nowej tożsamości, Wydawnictwo Presspublica, Warszawa 2000, p. 66.

33 A. Dudek, Historia i polityka w Polsce po 1989 roku..., p. 40.

34 „Gazeta Wyborcza” 9-10 February 2008, quoted from: E. Smolar, Wtadza i geografia pamięci..., p. 54.

35 A. Chojan, Fundamenty ideowe i cele polityki zagranicznej Prawa i Sprawiedliwości z perspektywy 2005 roku, „Myśl Ekonomiczna i Polityczna”, 2016, no 1, p. 205. 
foreign policies of the country and opposing the negative historical policies of other countries" ${ }^{36}$. Law and Justice was also the first political party that has officially included historical policy to its foreign policy.

The external dimension of Law and Justice historical policy was designed to restore the historical awareness of Poles in conditions of EU membership and to react to the attempts of rewriting history of WW2 by Germany and Russia, as well as to react also at the European level to harmful stereotypes such as "Polish concentration camps" suggesting Poland's responsibility for Holocaust ${ }^{37}$. The Law and Justice government took a decisive steps to prevent such allegations and rewriting of history. In 2006, it has introduced to the Polish Criminal Code an amendment penalizing slander against the Polish nation for participating in, organizing or being responsible for communist or Nazi crimes, punishable by up to three years of imprisonment ${ }^{38}$, and in 2018, has introduced (criticized worldwide) an amendment to the Act on the Institute of National Remembrance, to counteract the falsification of Polish history in Poland and in the world, and introduced a fine or imprisonment of up to three years for attributing to Poles the responsibility of, inter alia, for genocide committed against Jews during the war $^{39}$. Both legal changes have not, however, entered into force. On the other hand, it should be noted that since 2004, the Polish Ministry of Foreign Affairs has been implementing a policy of responding to, and countering untrue statements about Polish history in the world, including European media, in particular, the phrase "Polish concentration camps". Between 2008 and 2018 alone, Polish diplomatic missions made 1400 interventions on this issue ${ }^{40}$. In addition, private individuals have joined-in to counter this untrue and harmful statement by funding the "German Death Camps" campaign, which has resulted in billboards and trucks bearing this slogan appearing in Western European countries ${ }^{41}$.

The other important element of the European WW2 narrative, is the adoption of an ideological perspective of blame for the outbreak and crimes of World

${ }^{36}$ Ibidem.

37 A. Chojan..., p 211.

38 I.C. Kamiński, Kontrowersje prawne wokót przestępstwa polegajacego na pomawianiu narodu o popetnienie zbrodni, „Problemy Współczesnego Prawa Międzynarodowego, Europejskiego i Porównawczego", 2010, vol. VIII, p. 5-34.

${ }_{39}$ K. Sobczak, TK: Niekonstytucyjne zmiany w ustawie o IPN, https://www.prawo.pl/prawo/nowelizacja-ustawy-o-ipn-niekonstytucyjna-wyrok-tk,358702.html, access 3 IX 2021.

40 T. Żółciak, „Polski obóz koncentracyjny”. Nasze placówki dyplomatyczne w 2017 roku musiały interweniować 233 razy, https://forsal.pl/artykuly/1099678,polski-oboz-koncentracyjny-naszeplacowki-dyplomatyczne-w-2017-r-musialy-interweniowac-233-razy.html, access 30 VIII 2021.

${ }^{41}$ A. Szczepańska, Jak opowiedzieć o dramacie Polaków, „Do Rzeczy”, 13-19 IX 2021, no 37, p. 65. 
War 2, exemplified by the replacement of the word 'Germany' with 'Nazi' in historical discourse, which constitutes the next major misfit between European and Polish WW2 narrative. While liberal media have relatively quickly accepted this semantic change, it provoked, however, many critical reactions of politicians representing both models of historical policy in Poland. A good example of this is the debate that took place in 2005, in the European Parliament around the resolution commemorating the 60th anniversary of the liberation of AuschwitzBirkenau camp. Bogusław Sonik, the then MEP from liberal party Civic Platform (Platforma Obywatelska), who was responsible for negotiating the text of the resolution, mentions that during the negotiations: "representatives of the Social Democrats, Liberals and Greens opposed any mention of the fact that the Auschwitz-Birkenau camp was the work of the Third German Reich and that the word 'Germany' in the resolution turned out to be unacceptable. The term 'Nazi Germany' was also not accepted. Sarah Ludford, MEP, demanded that the European Parliament define the criminals responsible for the deaths of millions of people with one word only: 'Nazis'. It was strongly supported by the head of German socialists, Martin Schulz, who maintained that the resolution could not contain the word 'Germany', even with the adjective 'Nazi'. The representative of the German Greens, Daniel Cohn-Bendit, talked about Polish anti-semitism, the socialist Martine Roure - about the 'responsibility of some Poles' ${ }^{\prime 42}$. The controversy surrounding the text of the resolution was strongly criticized by the former Polish minister of foreign affairs and at the same time, a prisoner of the Auschwitz camp - Władysław Bartoszewski, who stated that "If politics is to be based on a big lie, I will say that the French put me in Auschwitz"43.

Another reaction to the replacing the guilt of the Germans at the European and global level with the guilt of the Nazis and the presence in the Western media of the phrase „Polish concentration camps” was the successful initiative of the Polish government to change the official name of the Auschwitz camp on the UNESCO World Heritage List, from "Auschwitz Concentration Camp" to "Former Nazi-German Concentration Camp Auschwitz-Birkenau". This action was dictated by fears that for the young generation, deprived of sensitivity and historical knowledge, the association of concentration camps with the criminal activities of Nazi Germany may not be obvious ${ }^{44}$. It also resulted from the belief

42 B. Sonik, Komunikat: Batalia o „Obóz Niemiec Nazistowskich” w 2005 roku na forum Parlamentu Europejskiego, http://www.boguslawsonik.pl/aktualnosci/2963, access 29 VIII 2021.

${ }^{43}$ Quoted from: „Super Express” 31 January 2005.

44 Museum of Auschwitz-Birkenau, http://auschwitz.org/muzeum/aktualnosci/polacy-chcaw-unesco-zmiany-wpisu-dotyczacego-bylego-obozu-auschwitz,466.html, Polacy chca w UNESCO zmiany wpisu dotyczacego bytego obozu Auschwitz, access 5 IX 2021. 
that the truth about the past is fragile and may be lost or become the subject of deliberate manipulation ${ }^{45}$.

To sum up, the Europeanization of Polish historical policy by downloading the European narrative about WW2 to the national level has brought about ambiguous results. On the one hand, it was quickly internalized by some liberal and left-wing political forces as an expression of their real or declarative aspirations to build a new (postmodern?) Polish historical identity that would fit into the European framework. On the other hand, it evoked strong opposition among the representatives of national-conservative circles, for whom the European narration about WW2 was perceived as an expression of misunderstanding and lack of sensitivity to the specificity of the Polish experience of occupation. It also showed that the Polish society, as well as its political elites, are not yet ready, and perhaps will not be, to accept uncritically the universalist European narrative about World War 2.

Poland's activities to promote its own historical narrative at the European level - The Uploading

There is no doubt that membership in the EU has created new opportunities for Poland to promote its own narrative about World War 2, as well as to combat the rewriting of history and harmful stereotypes. A particularly important area of these activities was the popularization of knowledge about the Polish contribution to the Allied war effort. Poles were present on every front of the World War 2, they contributed to the Battle of Britain, breaking the Enigma code and informing the Allies about the crime of the Holocaust, but these facts were not known to the greater public in Europe. Special emphasis in these activities, however, was placed on bringing the suffering of Poland and Poles under two totalitarian regimes during WW2 to the attention of foreign audiences

The process of transferring the Polish historical narrative about World War 2 to the European level has taken place through different channels. First, through European institutions - especially the European Parliament. Second, through actions of Polish diplomatic institutions in European countries, and third, though special projects and institutions dedicated to this task.

Undoubtedly, due to its representative character, the European Parliament has become an important forum for promoting the Polish historical narration. During parliamentary debates, Polish MEPs could present the Polish historical perspective and influence the content of adopted documents. A good example of

\footnotetext{
${ }^{45}$ E. Smolar, Wtadza i geografia pamięci..., p. 54.
} 
that is the EP resolution on Holocaust remembrance, anti-Semitism and racism adopted on 27 January 2005, in which, thanks to the involvement of Polish MEPs, the phrase 'Nazi death camp' was replaced with 'Nazi-German death camp'46. This was not just a semantic change, but a confrontation between two different narratives and historical sensitivities, in which the Polish narrative prevailed.

EP resolutions and accompanying debates, have also been used by Poland to counter the rewriting of history, especially in the face of the turn to a neoSoviet interpretation of history in the Russian Federation, in which Poland was accused of provoking World War 2 and the Molotov-Ribbentrop Pact was merely an act of self-defence by the USSR. An example of such a document is the EP resolution of September 19, 2019 on the 80th anniversary of the outbreak of World War II and the importance of European remembrance for the future of Europe. The thirteenth point of this document, which states: "(EU - KMM) Is deeply concerned about the efforts of the current Russian leadership to distort historical facts and whitewash crimes committed by the Soviet totalitarian regime and considers them a dangerous component of the information war waged against democratic Europe that aims to divide Europe, and therefore calls on the Commission to decisively counteract these efforts" ${ }^{\prime \prime}$, is particularly in line with the historical narrative on World War 2 that Poland has been promoting since re-gaining sovereignty. Moreover, the content of the entire document largely reflects the Polish perspective on World War 2, which highlights Nazi-German and Soviet crimes, as well as Poland as the first victim of these two criminal regimes.

Poland has also made other attempts to promote its narrative on the forum of European institutions. An example of this is the initiative of Polish MEPs to establish May 25 as the International Day of Heroes of the Fight Against Totalitarianism (the anniversary of the execution of Auschwitz hero Rotamaster Witold Pilecki), which aimed to give future generations "a clear example of the right attitude in the face of the threat of totalitarian enslavement" ${ }^{48}$.

${ }^{46}$ European Parliament resolution on remembrance of the Holocaust, Anti-semitism and Racism, The Holocaust, Antisemitism and Racism, P6_TA(2005)0018, https://www.europarl.europa.eu/doceo/document/TA-6-2005-0018_EN.html, access 25 VIII 2021.

47 European Parliament resolution of 19 September 2019 on the importance of European remembrance for the future of Europe, Importance of European remembrance for the future of Europe, P9_TA(2019)0021, https://www.europarl.europa.eu/doceo/document/TA-9-20190021_EN.html, access 25 VIII 2021.

${ }^{48}$ A. Fotyga, Postulujemy ustanowienie 25 maja dniem pamięci bohaterów walki z totalitaryzmami, https://www.radiomaryja.pl/informacje/a-fotyga-postulujemy-ustanowienie-25-maja -dniem-pamieci-bohaterow-walki-z-totalitaryzmami/, access 12 IX 2021. 
The Presidency of the EU, which Poland assumed in 2011, created a new channel for promotion of Polish historical narration on the European level. Although the activities promoting Poland did not include activities related to history, but rather to broadly defined culture, the multitude of initiatives prepared to support this process contributed to the growth of interest in Poland, including its history. The portal < poland.pl $>$, launched by the Ministry of Foreign Affairs and presenting information on Polish history, also served this purpose.

No less important was the activity of Polish diplomatic missions promoting Polish culture and history by commemorating important anniversaries related to Poland's war effort. A good example of this was the celebration of the 70th anniversary commemorating the participation of the 1st Independent Parachute Brigade (1SBS) of General Stanislaw Sosabowski in the Battle of Arnhem in 2014, and a series of events which took place in the United Kingdom in 2020, under the patronage of Ambassador of Poland, commemorating the Polish pilots who fought in the Battle of Britain in $1940^{49}$.

The third channel of uploading of Polish historical narrative about WW2, especially related to the suffering of Poland and Poles under two totalitarian regimes. were special projects and institutions dedicated to this task. In 2016, a new institution was established - Witold Pilecki Center for the Study of Totalitarianisms (now Witold Pilecki Institute for Solidarity and Valor), which main function is to ffacilitate the interdisciplinary and international analysis of Nazi and Soviet totalitarian regimes and the global consequences of their actions. The Institute is involved in many projects, including ones addressed to foreign teachers and educators, aimed at disseminating knowledge about the history of the Holocaust, Poland's role during World War 2 and its fight against two totalitarian systems ${ }^{50}$. Another institution involved in the promotion of the Polish narrative about World War 2 is the Polish National Foundation established in 2016, whose activities in that field include both film shows and the organization of outdoor events in Western countries about Poland and Polish participation in World War 2, as well as information campaigns ${ }^{51}$.

An important role in the transfer of Polish historical narrative to the European level is played by existing institutions such as the Institute of National Remembrance, the International Centre for Education about Auschwitz and the Holocaust at the Auschwitz-Birkenau Museum, and the Institute of New Media.

49 Website goniecpolski.com, https://goniec.com/po-godzinach/36186-zobacz-niezwykly -film-upamietniajacych-polakow-walczacych-o-anglie\%2010.09.2021, Zobacz niezwykty film upamiętniajacy Polaków walczacych o Anglię, access 25 IX 2021.

${ }_{50}$ Pilecki Institute, https://instytutpileckiego.pl/en/projekty, Projects, access 9 IX 2021.

${ }^{51}$ Polish National Foundation, https://www.pfn.org.pl/projects, Projects, access 11 IX 2021. 
In particular, the latter institution's initiative "We tell Poland to the world", supported by the IPN, was meant to bring Polish history closer to the citizens of the EU countries, through the publication of works on Polish history in dozens of newspapers, magazines and websites ${ }^{52}$.

The process of promoting the Polish historical narrative at the European level is strengthened by the Polish Ministry of Foreign Affairs. A key role is played by the Department of Public and Cultural Diplomacy, established in the Ministry structure in 2009. Its task is to communicate and explain to foreign audiences the decisions made by the Polish government, as well as to promote Polish culture and history in order to build a positive image of the country. The Department supports all initiatives that contribute to a positive image of Poland abroad, as well as raising awareness of the Polish historical narrative. A good example of this is the Congress of Foreign Researchers of Polish History, recognized by the Ministry of Foreign Affairs as an important channel for the dissemination of knowledge about Polish history, as well as the works of English-language historians such as Norman Davies and Timothy Snyder who played a significant role in promoting the Polish historical narrative abroad ${ }^{53}$.

The need to strengthen the visibility of Polish historical narrative abroad, including in the EU, was reflected in the institutionalization of Polish historical diplomacy. The process intensified after 2015, when the national-conservative Law and Justice party won re-election. In 2016, the Minister of Foreign Affairs established the Council for Historical Diplomacy as a subsidiary and advisory body responsible for: $1 /$ co-creating the strategy of historical policy of the Polish state and proposing its implementation with regard to foreign countries; 2/ developing recommendations and proposals for priorities for Polish foreign missions in the field of historical diplomacy; 3/ supporting the actions of the Ministry of Foreign Affairs aimed at counteracting the 'false codes of remembrance' in the foreign media, in particular, preparing the proposals and recommendations in this regard; 4/ inspiring activities aimed at creating and strengthening chairs of Polish history or Polish studies at foreign universities, as well as scholarship programs for foreign historians in Poland; 5 / substantive cooperation in preparing proposals for undertakings promoting Polish historical narration abroad (conferences, celebrations of historical anniversaries, exhibitions, films, Internet presentations); 6/ supporting

${ }^{52}$ Instytut of National Remembrance, https://ipn.gov.pl/pl/aktualnosci/129433,Opowiadamy -Polske-swiatu-o-najnowszej-historii-Polski-w-prasie-zagranicznej.html, Opowiadamy Polske światu - o najnowszej historii Polski w prasie zagranicznej, access 20 IX 2021.

${ }^{53}$ Historical Website: Dzieje.pl, https://dzieje.pl/aktualnosci/msz-za-granica-jest-potrzebne-zrozumienie-polskiej-tozsamosci-i-historii, MSZ: za granica jest potrzebne zrozumienie polskiej tożsamości i historii, access 10 IX 2021. 
the efforts of the Ministry of Foreign Affairs in promoting the knowledge of Polish history in mass culture abroad, especially through proposals and recommendations addressed to representatives of Polish diaspora and Polish institutions abroad ${ }^{54}$. In the same year, work began on the Strategy of Polish Historical Policy, but to this day the document has not been adopted.

The positive influence of the process of Europeanization of the Polish narration about World War 2 through uploading on the historical awareness of Europeans is confirmed by public opinion surveys. An international survey of European knowledge of Poland's role in World War 2 conducted in 2020 by United Survey for Polish newspaper - Dziennik Gazeta Prawna and radio station - RMF FM, showed that European knowledge in this area does not differ significantly from that of Poles, and is convergent with the Polish vision of World War 2 history. The questions concerned the beginning of World War 2, Polish attitudes towards rescuing Jews during the war, the perception of Poles as war victims and the role of the Soviet Union in enslaving Central and Eastern Europe as a result of its actions against Nazi-Germany. According to the majority of respondents, the Soviet Union was not involved in the war in as of 1941, but had been so since September 1939, the time of its joint aggression against Poland with the Third Reich. Most respondents also agreed with the statement that Poles were victims of the WW2 and at the same time tried to save Jews. They also shared the belief that the Eastern front activity of the Third Reich by the Red Army brought about the domination of the USSR in Central and Eastern Europe ${ }^{55}$.

\section{Conclusions}

The article dealt with the problem of Europeanization of Polish historical policy. On the basis of the conducted analysis, it is possible to answer positively to the question posted in the article's title. Through the efforts of government and non-governmental bodies and persons, the level of knowledge about the role of Poland and Poles in WW2 has increased in EU member states, as has the level of awareness of Polish historical reality. This is demonstated in the public poll results presented above. However, this should not be the cause for too much optimism. The identified misfits between European and Polish narrative about WW2 reveal that there is still a lot of work to do on Polish side.

${ }^{54}$ Zarządzenie nr 24 Ministra Spraw Zagranicznych z dnia 11 lipca 2016 r. w sprawie Rady Dyplomacji Historycznej, Dz.Urz.MSZ.2016.32.

55 A. Grochot, Sondaż: Co czwarty Niemiec uważa, że II wojna światowa nie rozpoczęta się od inwazji III Rzeszy i ZSRR na Polskę, https://www.rmf24.pl/fakty/polska/news-sondaz-co-czwartyniemiec-uwaza-ze-ii-wojna-swiatowa-nie-roz,nId,4281566\#crp_state=1, access 20 IX 2021. 
In an attempt to answer the questions formulated in the Introduction, it should be stressed that in both dimensions, Poland membership in the EU has visible impact. Taking into account the results of the aforementioned public opinion polls, EU membership has created an important channel for Poland to communicate its own historical narrative at the pan-European level, thanks to which many facts unknown to the European public have penetrated the public consciousness and found their expression in official EU documents. It should also be emphasized that the uploading mechanism proved to be more effective in terms of shaping the European historical narrative, as manifested by the 2019 EP resolution on historical memory, than the downloading mechanism, and the attempt to transfer the European narrative about World War 2 to the Polish level.

\section{Bibliography}

\section{Sources}

- European Parliament resolution of 19 September 2019 on the importance of European remembrance for the future of Europe, Importance of European remembrance for the future of Europe, P9_TA(2019)0021, https://www.europarl.europa.eu/doceo/ document/TA-9-2019-0021_EN.html.

- European Parliament resolution on remembrance of the Holocaust, Anti-semitism and Racism, The Holocaust, Antisemitism and Racism, P6_TA(2005)0018, https:// www.europarl.europa.eu/doceo/document/TA-6-2005-0018_EN.html.

- Fotyga A., Postulujemy ustanowienie 25 maja dniem pamięci bohaterów walki z totalitaryzmami, https://www.radiomaryja.pl/informacje/a-fotyga-postulujemy-ustanowienie-25-maja-dniem-pamieci-bohaterow-walki-z-totalitaryzmami/.

- Polityka historyczna - za i przeciw, Dyskusja z udziałem P. Dukielskiego, M. Cichockiego, M. Kuli, A. Wernera, K. Mazura, „Mówią Wieki”, 2006, no 8.

- Sonik B., Komunikat: Batalia o „Obóz Niemiec Nazistowskich” w 2005 roku na forum Parlamentu Europejskiego, http://www.boguslawsonik.pl/aktualnosci/2963.

- Website: Teologia Polityczna, https://teologiapolityczna.pl/ii-wojna-swiatowa-iwspolczesne-narracje-historyczne-rozmowa-z-piotrem-semka, II wojna światowa i współczesne narracje historyczne. Rozmowa z Piotrem Semką.

- Zarządzenie nr 24 Ministra Spraw Zagranicznych z dnia 11 lipca 2016 r. w sprawie Rady Dyplomacji Historycznej, Dz.Urz.MSZ.2016.32.

\section{Literature}

- Börzel T., Risse T., Conceptualizing the Domestic Impact of Europe [in:] The politics of Europeanization, ed. R. Featherstone, C. Radelli, Oxford University Press, Oxford 2003, p. 57-82.

- Chojan A., Fundamenty ideowe i cele polityki zagranicznej Prawa i Sprawiedliwości z perspektywy 2005 roku, „Myśl Ekonomiczna i Polityczna”, 2016, no 1, p. 202-228. 
- Cowles M., Caporaso J., Risse T., Europeanization and domestic change. Transforming Europe, Cornell University Press, New York 2001;

- Dudek A. , Historia i polityka w Polsce po 1989 roku [in:] Historycy i politycy: polityka pamięci w III RP, ed. P. Skibiński, T. Wiścicki, M. Wysocki, Wydawnictwo DiG oraz Muzeum Historii Polski, Warszawa 2011, p. 33-57.

- Grabbe H., How does the Europeanization affect the CEE governance? Conditionality, diffusion and diversity, „Journal of European Public Policy”, 2001, vol. 8, issue 6, p. 1013-1031.

- Grochot A., Sondaż: Co czwarty Niemiec uważa, że II wojna światowa nie rozpoczęła się od inwazji III Rzeszy i ZSRR na Polskę, https://www.rmf24.pl/fakty/polska/newssondaz-co-czwarty-niemiec-uwaza-ze-ii-wojna-swiatowa-nie-roz,nId,4281566\#crp_ state $=1$

- Gross J.T., Sąsiedzi. Historia zagłady żydowskiego miasteczka, Wydawnictwo Pogranicze, Sejny 2000.

- Kamińska J., Europeizacja polskiej polityki zagranicznej, htps://www.ce.uw.edu.pl/ pliki/pw/3-2008_Kaminska.pdf.

- Kamiński I.C., Kontrowersje prawne wokół przestępstwa polegającego na pomawianiu narodu o popełnienie zbrodni, „Problemy Współczesnego Prawa Międzynarodowego, Europejskiego i Porównawczego", 2010, vol. VIII, p. 5-34.

- Kącka K., Polityka historyczna: kreatorzy, narzędzia, mechanizmy działania - przykład Polski [in:] Narracje pamięci. Między polityką a historią, ed. K. Kącka, J. PiechowiakLamparska, A. Ratke-Majewska, Wydawnictwo Naukowe UMK, Toruń 2015, p. 59-82;

- Majcherek J.A., W poszukiwaniu nowej tożsamości, Wydawnictwo Presspublica, Warszawa 2000.

- Major C., Europeanization of Foreign and Security Policy - Undermining or rescuing the nation state?, „Politics”, 2005, vol. 25, p. 175-190;

- Miskimmon A., Paterson W.E., Foreign and Security Policy: On the Cusp Between Transformation and Accommodation [in:] Germany, Europe and Politics of Constraint, ed. K. Dyson, K.H. Goetz, Oxford University Press, Oxford 2004, p. 325-346.

- Olsen J., Many faces of Europeanization, „Journal of Common Market Studies” 2002, vol. 40, no 5, p. 921-952.

- Östling J., Swedish Narratives of the Second World War: A European Perspective, "Contemporary European History", 2008, vol. 17, issue 2, p. 197-211.

- Ponczek E., Polityka historyczna w Polsce - od oglądu retrospektywnego do refleksji o następstwach przyszłościowych [in:] Narracje pamięci. Między polityką a historią, ed. K. Kącka, J. Piechowiak-Lamparska, A. Ratke-Majewska, Wydawnictwo Naukowe UMK, Toruń 2015, p. 29.58.

- Radelli C., The Europeanization of public policy [in:] The politics of the Europeanization, ed. C. Radelli, K. Featherstone, Oxford University Press, Oxford 2003, p. 27-56;

- Sawicki J.Z., Pamięć i polityka historyczna na przykładzie walski z legendą powstania warszawskiego [in:] Narracje pamięci. Między polityką a historią, ed. K. Kącka, J. Piechowiak-Lamparska, A. Ratke-Majewska, Wydawnictwo Naukowe UMK, Toruń 2015, p. 133-146.

- Smith M.E., Conforming to Europe: the domestic impact of the EU policy cooperation, "Journal of the European Public Policy" 2000, vol. 7, issue 4, p. 613-631. 
- Smolar E., Władza i geografia pamięci [in:] Pamięć jako przedmiot władzy, ed. P. Kosiewski, Fundacja im S. Batorego, Warszawa 2008, p. 49-74.

- Sobczak K., TK: Niekonstytucyjne zmiany w ustawie o IPN, https://www.prawo.pl/ prawo/nowelizacja-ustawy-o-ipn-niekonstytucyjna-wyrok-tk,358702.html.

- The politics of Europeanization, eds. C. Radelli, K. Featherstone, Oxford University Press, Oxford 2003;

- Włodkowska-Bagan A., Kultura strategiczna Polski [w:] Polityka zagraniczna Polski w zmieniającym się ładzie międzynarodowym, ed. R. Zięba, T. Pawłuszko, Wydawnictwo Uniwersytetu Jana Kochanowskiego w Kielcach, Kielce 2016, p. 53-76.

- Wolff-Powęska A., Polskie spory o historię i pamięć. Polityka historyczna, „Przegląd Zachodni", 2007, nr 1, p. 3-44;

- Wong R., The Europeanization of Foreign Policy [in:] International Relations and the European Union, ed. By C. Hill, M. Smith, Oxford University Press, Oxford 2011, p. $149-170$.

- Żółciak T., „Polski obóz koncentracyjny”. Nasze placówki dyplomatyczne w 2017 roku musiały interweniować 233 razy, https://forsal.pl/artykuly/1099678,polski-obozkoncentracyjny-nasze-placowki-dyplomatyczne-w-2017-r-musialy-interweniowac233-razy.html.

\section{Websites:}

- Dzieje.pl, https://dzieje.pl/.

- Goniecpolski, https://goniec.com/.

- Instytut Pamięci Narodowej, https://ipn.gov.pl/.

- Instytut Pileckiego, https://instytutpileckiego.pl/en.

- Muzeum Auschwitz-Birkenau, http://auschwitz.org/.

- Polska Fundacja Narodowa, https://www.pfn.org.pl/.

- TVN24, https://tvn24.pl/.

\section{Newspapers:}

- Do Rzeczy

- Gazeta Wyborcza

- Super Express

Summary: History is an important element of national domestic and foreign policy. Consistent cultivation of national myths contributes to the strengthening of national identity and the image of the state outside, and skilfully conducted historical policy fosters the building of international ties and the realization of own interests. The main assumption of the article is the recognition that EU membership is an important instrument of Poland's historical policy. The inability of communist Poland to conduct its own historical narrative at the international level contributed to the consolidation of many unfair or even false beliefs and stereotypes about Poland. Changing them is a difficult and long-term task. Undoubtedly, EU membership has opened new opportunities for Poland in this respect. The paper aims to analyse the process of Europeanization of Polish 
historical policy on WW2 in two dimensions: first, the internal, i.e. to answer the question to what extent Poland's membership in the EU has influenced the internal discourse around historical policy; and second, the external, i.e. to what extent actions taken by Poland has influenced historical awareness of the member states and the position of European institutions regarding historical issues related to WW2.

Key words: Europeanization, Polish historical policy, WW2

\section{Europeizacja polityki historycznej Polski - od ingnoracji do zrozumienia?}

Streszczenie: Historia jest ważnym elementem polityki wewnętrznej i zagranicznej państw. Konsekwentne kultywowanie mitów narodowych przyczynia się do umacniania tożsamości narodowej i wizerunku państwa na zewnątrz, a umiejętnie prowadzona polityka historyczna sprzyja budowaniu więzi międzynarodowych i realizacji własnych interesów. Głównym założeniem artykułu jest uznanie, że członkostwo w UE było ważnym instrumentem polityki historycznej Polski. Niezdolność PRL do prowadzenia własnej narracji historycznej na forum międzynarodowym przyczyniła się do utrwalenia wielu niesprawiedliwych, a nawet fałszywych przekonań i stereotypów na temat Polski. Ich zmiana jest zadaniem trudnym i długotrwałym. Niewątpliwie członkostwo w Unii Europejskiej otworzyło przed Polską nowe możliwości w tym zakresie. Celem artykułu jest analiza procesu europeizacji polskiej polityki historycznej dotyczącej II wojny światowej w dwóch wymiarach: po pierwsze, wewnętrznym, tj. odpowiedź na pytanie, w jakim stopniu członkostwo Polski w UE wpłynęło na wewnętrzny dyskurs dotyczący polityki historycznej? I drugi, zewnętrzny, tj. w jakim stopniu podejmowane przez Polskę działania wpłynęły na świadomość historyczną państw członkowskich i stanowisko instytucji europejskich wobec kwestii historycznych związanych z II wojną światową?

Słowa kluczowe: europeizacja, polityka historyczna Polski, II wojna światowa 